Tér és Társadalom 3. évf. 1989/2. 121-122. p.

KRÓNIKA

\title{
BESZÁMOLÓ AZ RKK KERETEI KÖZÖTT MEGINDULT FÖLDRAJZI SZEMINÁRIUMRÓL
}

Az MTA Regionális Kutatások Központja 1988. nyara óta az országnak immár hat városában múködik. Kutatóink a különböző diszciplinákat térben és iđôben elkülönülve múvelik, alig van mód arra, hogy az intézet egésze, annak alkotó kollektívája közösen is gondolkodhassék egy-egy új szakmai problémán, felvetésen, konce pción vagy eredményen.

Ezen meditálva fordultunk felhivással a központ valamennyi kutatóhelyéhez, hogy rendszerességre törekedve szervezzünk meg egy olyan szemináriumsorozatot, amelyik vérbeli szakmai vitáknak adhatna teret, fórumot. Az erre szánt kéziratokat a szervezó bizottság megküldi majđ valamennyi érdeklődőnek, akik természetesen - szakmánk jellegéból adódóan - nemcsak intézetünk tagjai lehetnek. Tervezzük azt is, hogy hivatásos „,vitatkozókat” kérünk fel, vagy egy-egy neves küllföldi tuđóst hívunk meg. Kerülni szeretnénk azonban a védések, vagy a tudományos konferenciák néha túlszabályozott, unalmas formalizmusát. lgazi szakmai - a földrajz mellett a társtudomány ok eredményeinek integrálására is képes - múhelyvitákat akarunk, minden, a té mák iránt érdeklő đő területi kutató számára.

Esetenként pedig, ha a folyóiratunk szerkesztösége úgy itéli, a Tisztelt Olvasó számára is hozzáférhetôvé tesszük a vitaanyagokat, az érdekesebb hozzászólásokat.

„Vitázni szükséges"

A szervezó bizottság nevében:

CSATÁRI BÁLINT

\section{BESZAMOLÓ AZ MTA REGIONÁLIS TUDOMÁNYOS BIZOTTSAGÁNAK 1988. NOVEMBER 10-I ÜLÉSÉRÖL}

Az ülésen BARTKE ISTVÂN tájékoztatót adott a Borsođ-Abaúj-Zemplén megye térségi fejlesztési programjával kapcsolatos munkálatokról. A tájékoztató szerint három szálon folyó munkáról van szó: a központi kormányzat, a megyei szervek, illetve tudományos intézmények részvételével. A cél kettốs: röviđ távú válságmenedzselố intézkedési terv kiđolgozása, illetve 1989 közepéig a Minisztertanács számára hosszú távú térségi fejlesztési program elkészítése. A térségi válságból (depresszió ból) való kimozđulás föbb elemei az alábbi irányok köré rendezhetôk: a térségi nehézipari túlsúly csökkentése, a termékek feldolgozottsági fokának növelése, kis- és középvállala tok létesítése, a mezőgazdasági érđekeltségi rendszer korszerúsítése (földbérleti rendszer), a térségi infrastrukturális hálózatfejlesztés gyorsítása. A célok megvalósításának eszközei között vállalati források, központi beruházási támogatások, térségi preferenciák, regionális hatókörü banki eszközök, illetve külföldi (világbanki) források bevonása jöhet szóba. A tájékoztatót követô vitában hangsúlyt kapott a térségi đepressziónak a megyehatáron túllépő regionális léptéke, az ágazati, vállalati válság, illetve az átfogó térségi feszültségek közötti tisztázandó viszony, a munkahelyteremtést, illetve a lakó- és munkahely-változtatást ösztönzố kettôs válságkezelési alternatíva, s annak hangsúlyozása, hogy a megoldás egyaránt kíván helyi és központi eszközöket, cselekvést, s $\mathrm{az}$, hogy a probléma megoldása semmiképp nem szúkíthe tó le az ipari munkahelyteremtés ösztönzésére. 
A vita összegzéseként megfogalmazódott, hogy az MTA RTB - független szakértő-testületként - kész részt venni az elkészülő koncepció véleményezésében.

Második napirendi pontként - az elözetesen megküldött kutatási koncepcióvázlat alapján - megvitatásra került „,A magyar válság földrajza” c. tervezet, amelyet ENYEDI GYƠRGY terjesztett elö.

Az elốterjesztés vitájában a bizottság aktuális, érđemi feladatnak minősítette a szintézist felvállaló kutatási tervezetet. Annak egyes részkérdéseihez, illetve ezek egy máshoz való tartalmi és logikai viszonyának problémájához, egyes témakörökkel való kiegészítéséhez, az adott közelítés jellemzöen ,ágazati" logikájához kapcsoló đó kérdések és hozzászólások mellett elsôsorban azt firtatták a hozzászólók, hogy vajon adottak-e a feltételek (a szellemi, tudományos muníció) ahhoz, hogy a témakört - a javaslat szerint - viszonylag rövid idő, egy-másfél év alatt színvonalasan tárgyalni lehessen. A bizottság támogatásáról biztosította az előterjesztőt a munka szervezeti, financiális feltételei megteremtésének elindításában. A viszonylag rövid idôn belül elkészítendő résztanulmányok, illetve ezek szintézise birtokában - $\mathrm{s}$ nem e módszerrel szembeállítva - lehet indokolt annak végiggondolása is, hogy az adott témakörben esetleg hosszabb távú, új kutatási irányokat, té mákat is felölelő munka inđuljon. A tematika szerinti munka szervezését, koordinálását az MTA Regionális Kutatások Központja végzi, a tevékenységet a bizot tság figyelemmel kíséri.

NEMES NAGY JÓZSEF

\title{
AZ IPAR KUTATASPOLITIKÁJA ÉS A REGIONÁLIS SZELLEMI CENTRUMOK FEJLESZTÉSÉNEK ÖSSZEFÜGGÉSEI
}

\author{
(Beszámoló az Ipari Minisztérium munkabizottságának \\ 1988. november 11-i üléséról)
}

Szellemi eröforrásaink területi megoszlása szélsôségesen differenciálódott. Míg az ipari munkaerố közel 80\%-a, addig a kutatással-fejlesztéssel foglalkozóknak csak alig 30\%-a dolgozik vidéken. A területi különbségek már létrejöttek a II. világháború előtti Magyarországon is, az azóta eltelt évtizedekben a Budapest-vidék polarizálódás azonban tovább erôsödött.

Az Ipari Minisztérium e téma kutatására munkabizottságot szervezett tudományos kutatókból, politikai munkatársakból, gazđasági szakemberekből. A munkabizottság elnöke Enyedi György akadémikus, titkára Horváth Ảrpád (IPM), koordinátora Szentgyörgyi Zsuzsa (IPM).

A munkabizottság feladatai közé tartozik, hogy megfogalmazza e kutatás tudományos kérđéseit; a korábbi kutatások, információk alapján helyzetképet dolgozzon ki; az ipari fejlesztési politika számára szakvéleményeket készítsen; és körvonalazza a problémakör komplex kutatásainak feladatait. 